\title{
Stock investment analysis, idiosyncratic risk and abnormal return
}

\author{
Suyanto \\ Institute of Economic Science IPWI, Jakarta, Indonesia
}

Florens Natalia Handayani Sibarani

Pancasila University, Jakarta, Indonesia

\begin{abstract}
The purpose of this research is to examine the effect of value of earning per price and book to market ratio, firm size shown by market capitalization, stock liquidity by using turnover rate and Idiosyncratic Risk depicted by Idiosyncratic Risk Volatility (IVol) on Abnormal Return of stocks owned by the entities from the property and real estate sector listed in Indonesia Stock Exchange during the research period of the year 2012 - 2016. The analysis model used in this research is multiple regression with the test tool of SPSS version 21 . There are four hypotheses which are tested by the t-test to provide evidence there is significant effect and by the F-test to provide evidence that there is simultaneous significant effect of variable $\mathrm{x}$ to variable $\mathrm{y}$. The study results show that value from E/P ratio and B/M ratio had insignificant effect on Abnormal return, while the other factors Firm Size, Stock Liquidation, and Idiosyncratic Risk Volatility had significant effect on Abnormal return. B/M ratio and Turnover rate show negative effect on Abnormal Return, while E/P ratio, Firm Size and Idiosyncratic Risk Volatility show positive effect on Abnormal Return.
\end{abstract}

Keywords: value, earnings-price, book to market, market capitalization, idiosyncratic risk volatility

\section{INTRODUCTION}

\subsection{Background}

An announcement containing relevant information is one that will give an abnormal return to the market. The existence of the abnormal return phenomenon attracts the attention of investors and researchers towards any factors that can significantly affect the abnormal return. Some researchers have tried to examine various factors that influence $a b-$ normal return by using factors such as the value of $\mathrm{E} / \mathrm{P}$ ratio \& $\mathrm{B} / \mathrm{M}$ ratio, firm size, stock liquidity, and idiosyncratic risk.

\subsection{Purpose of Study}

The purpose of this study is to empirically prove whether the value of $\mathrm{E} / \mathrm{P}$ ratio \& $\mathrm{B} / \mathrm{M}$ ratio, firm size, stock liquidity, and idiosyncratic risk significantly influence the abnormal return of the stock partially and simultaneously on Indonesia Stock Exchange (BEI).

\section{LITERATURE REVIEW AND HYPOTHESIS DEVELOPMENT}

\subsection{Value of $E / P$ ratio and $B / M$ ratio}

According to Jiang \& Lee (2009), financial and income ratios can be used to predict stock returns both long and short-term. An active investor needs to pay attention to financial ratios because of market risks that occur all the time. Basu (1977) and Basu (1983) studied up to 1,400 companies listed on the New York Stock Exchange from 1956 to 1971 and 1963 to 1980 . Both studies showed that in both periods, the expected returns were negatively related to earnings-price $(\mathrm{E} / \mathrm{P})$ ratio. On average, portfolios with low E/P ratios result in higher risk-adjusted returns than portfolios with high $\mathrm{E} / \mathrm{P}$ ratios.

The most popular financial ratio concerning the market risk anticipation is a book-to-market ratio. Liu (2009) proves in his research on Chinese Stock Exchange that $\mathrm{B} / \mathrm{M}$ ratio is positively related to abnormal return.

\subsection{Firm Size}

Firm size is often used as an indicator of the possibility of the bankruptcy of a company, where companies with larger sizes are considered more able to face the crisis in running their business. Firm size is a measure of a company that can be seen from market capitalization. The main factor in the Fama-French three-factor model tested by Fama \& French (1993) to determine the value of a financial security was the size factor or the market capitalization of a security or portfolio of 
securities. Market capitalization was the market price of a share or common stock multiplied by the number of outstanding shares (Berk \& DeMarzo 2014).

\subsection{Stock Liquidity}

According to Conroy et.al (1990) in Setiyanto (2006), the most common parameters used to measure the liquidity of a stock are:

a. Trading volume

b. Spread level

c. Information flow

d. Number of shareholders

e. Number of outstanding shares

f. Transaction cost

g. Stock price

h. Turnover rate

The turnover ratio can be used as an indicator of the level of stability and volatility of a stock's value. The low turnover ratio gives the investor a hint that quick buying does not cause the stock price to increase due to the availability of multiple shares. However, high turnover ratios provide clues that stocks are less available so that high demand will affect stock price increases.

\subsection{Idiosyncratic Risk}

Various theories assume that idiosyncratic risk is positively correlated with stocks' expected returns. The idea behind this assumption is that investors who do not diversify their investments demand an additional return in order to bear the risk of their portfolios. The main exponents of these theories are Levy (1978) and Merton (1973).

The empirical existence of a relationship between idiosyncratic risk and the expected returns has been tested for a considerable amount of time. Goyal \& Santa-Clara (2003), who found evidence that market variance does not predict returns, should be highlighted. However, they found a positive and significant relationship between average stock variance, which greatest component is an idiosyncratic risk and market returns. Goyal \& Santa-Clara (2003) used a portfolio of stocks traded on the New York Stock Exchange (NYSE), American Stock Exchange (AMEX) and Nasdaq exchanges between August 1963 and December 1999 (Primo, 2012).

\subsection{Abnormal Return}

In his book "What Works on Wall Street: The Classic Guide to the Best-Performing Investment Strategies of All Time", 2012, James P. writes,
"Abnormal Returns seeks to demystify investment strategies and help investors find the path that is right for them, and, in so doing, should help investors succeed on the sometimes perilous road to investment success."

Abnormal return is the return earned by investors who are not in accordance with expectations. Abnormal return is the difference of return earned (actual return) with expected return (expected return). The difference of abnormal return will be positive (excess return) if the return obtained is higher than the expected return or calculated return. While the abnormal return will be negative if the return earned is lower than the expected return or return is calculated.

\subsection{Hypothesis Development}

Fama \& French (1992) introduced a three-factor model in researching the relationship between abnormal returns with $\mathrm{B} / \mathrm{M}$ ratios. In research on the New York Stock Exchange (NYSE), American Stock Exchange (AMEX), and NASDAQ, it was found that $\mathrm{E} / \mathrm{P}$ ratio and $\mathrm{B} / \mathrm{M}$ ratios both could influence future stock abnormal returns. Hypothesis: "Value of E/P ratio and $B / M$ ratio both have a significant effect on abnormal return".

Firm Size shown from the market capitalization value can be used as a reference to answer whether the company is worth buying. Large companies are believed to be more resilient to crisis than small ones. The ability of firms to stay afloat in generating profit becomes the consideration of investors in choosing shares that are worth buying, selling or maintaining. Thus, the size of the company can affect the abnormal return. Hypothesis: "Firm size has a significant effect on abnormal return."

Liquidity itself plays an important role in the price of an asset (Malkiel \& Xu 2004). Although various researchers have different definitions and measurements, it is generally agreed that high liquidity is defined as a measure of the ability of an investor to sell an asset without experiencing a significant loss of its fair value. Logically, illiquid assets will be difficult to sell, which will have an impact on the decline in asset prices. Hypothesis: "Stock liquidity has a significant effect on abnormal return."

Bali \& Cakiki (2006) mentioned that firms with high total idiosyncratic risk will be charged high returns to cover the risk of not being diversified perfectly. In this study, the idiosyncratic risk will be measured using idiosyncratic volatility (Ivol), which according to Tinic \& West (1986) and Malkiel \& Xu (1997), the higher the volatility of idiosyncratic risk, the higher the stock return of a firm. Hypothesis: 
"Idiosyncratic risk has a significant effect on abnormal return."

After reviewing each of the partially independent variables in terms of their relation to the dependent variable, it is necessary to simultaneously examine all independent variables in relation to the dependent variable to see whether the existing partial relationships between independent and dependent variables can be reinforced or weaken the relationships. Hypothesis: "Value of $E / P$ ratio and $B / M$ ratio, firm size, stock liquidity and idiosyncratic risk simultaneously have a significant effect on abnormal return."

\section{METHODOLOGY}

\subsection{Estimation Model}

The type of this research was quantitative research using secondary data with a source of information from Indonesia Stock Exchange in the form of financial statement which was published for 5 years from 2012 until 2016. While the sample research method used was purposive sampling in which the researcher has a certain criterion or purpose to the sample to be studied, where the sampling is done by choosing to deliberately adjust to the purpose of research. This study used panel data which is a combination of time series and cross-section data. Time series data consists of annual data for 5 years, 2012 - 2016. Based on the method of purposive sampling, the number of cross-section data consists of 35 research objects.

\subsection{Variable Measurements}

Dependent variable---abnormal return is the differences between a single stock or portfolio's performance and the expected return over a set period of time.

Independent variables $\mathrm{E} / \mathrm{P}$ ratio is derived from income per share divided by stock price. The Bookto-Market $(\mathrm{B} / \mathrm{M})$ ratio shows the firm's value by comparing the book value of the company with its value in the market. Firm size is measured using the market capitalization value, i.e. the value of the issuer's shares multiplied by the number of shares traded. Turnover ratio is often used to measure stock liquidity by counting the number of shares traded in one period divided by the number of outstanding shares. The volatility of Idiosyncratic Risk is derived from the standard deviation of residuals from Idiosyncratic Risk. Idiosyncratic risk (CAPM model):

Risk. Idiosyncratic risk (CAPM model):

$\mathrm{Ri}, \mathrm{t}=\alpha \mathrm{i}, \mathrm{t}+\beta \mathrm{i}, \mathrm{t} .(\mathrm{Rm}, \mathrm{t}-\mathrm{Rf}, \mathrm{t})+\varepsilon \mathrm{i}, \mathrm{t}$ where $\mathrm{Ri}, \mathrm{t}=$ stock return; $\mathrm{Rm}, \mathrm{t}=$ market return; $\mathrm{Rf}, \mathrm{t}$ $=$ risk-free return; $\varepsilon \mathrm{i}, \mathrm{t}=$ idiosyncratick risk.

Idiosyncratic Risk volatility (IVOL) will be measured using (Bali \& Cakiki 2006):

$\operatorname{IVOL~} \mathrm{i}, \mathrm{t}=\sqrt{\operatorname{Var}(\varepsilon \mathrm{i}, \mathrm{t})}$

\subsection{Data Analysis}

This research used a quantitative method with multiple regression analysis tool. Multiple regression analysis was used to test the effect of value, firm size, liquidity, and idiosyncratic risk to the abnormal return of stock of property \& real estate firms listed on BEI. Classic assumption test was required to know the condition of data used in the research. The purpose was to obtain an appropriate analysis model. This linear regression analysis model requires assumption test on data which includes normality test using scatter plot, multicollinearity test with correlation matrix between independent variables, heteroscedasticity test using plot between the predicted value of bound variable (ZPRED) with residual (SRESID) autocorrelation test through Durbin-Watson test (DW test). Thereby, the results of regression analysis meet the criteria BLUE (best linear unbiased estimator).

The test of the partial regression coefficient is done by t-test. With a $95 \%$ confidence level, the $\mathrm{t}$ count value of each regression coefficient is then compared with the t-table value. While testing of regression coefficients simultaneously performed with F-test. With a significance level of 0.05 from the $\mathrm{F}$ ratio of each regression coefficient then compared with the $\mathrm{F}$ - table value. If $\mathrm{F}$ ratio $>\mathrm{F}$ table or prob-sig $<\alpha=0.05$ means that all independent variables significantly influence the dependent variable.

\section{RESULTS AND DISCUSSION}

\subsection{Research Findings}

Normality test is done by using KolmogorovSmirnov test to find out whether the data is normally distributed. The test results show that the residual regression has a sig value. $\mathrm{Z} 0.726$ which is above 0.05 . This shows the regression model is normally distributed. The five independent variables have a number TOLERANCE close to the number 1 and the VIF or Variance Inflation Factor smaller than 10. Thus, it can be said that the model formed shows no symptoms of multicollinearity. Scatter Plot test result shows no clear or spread pattern. This supports the evidence of no heteroscedasticity problem in the regression model. A further test was conducted to determine whether there is a correlation of variables 
that exist in the prediction model with time changes Value DW $=2.685$ is greater than the upper limit $(\mathrm{dU})$ of 0.878 and less than $4-\mathrm{dU}(4-0.878)=3.122$, so it can be concluded that there is no autocorrelation.

The value of Adjusted R-Square in Table 4.6 above is 0.327 thus the value indicates that $42.6 \%$ Abnormal Return variable can be explained by independent variables consisting of $\mathrm{E} / \mathrm{P}$ ratio, $\mathrm{B} / \mathrm{M}$ ratio, Firm Size, Turnover Rate and Idiosyncratic Risk Volatility, while the rest of $57.4 \%$ is influenced by other variables that cannot be explained by the model in this study.

The result of t-value $0.552<\mathrm{t}$-Table that is equal to 2.045 and significance value $\mathrm{X} 1$ to $\mathrm{Y}$ that is equal to 0.585 which means $>0.05$. Thus, it can be concluded that $\mathrm{H} 0$ is accepted and $\mathrm{H} 1$ is rejected that $\mathrm{E} / \mathrm{P}$ ratio has no significant effect on the abnormal return of the stock.

The result of $\mathrm{t}$-value $0.403<\mathrm{t}$-Table that is equal to 2.045 and significance value $\mathrm{X} 2$ to $\mathrm{Y}$ is equal to 0.690 which means $>0.05$. Thus, it can be concluded that $\mathrm{H} 0$ is accepted and $\mathrm{H} 1$ is rejected that the $\mathrm{B} / \mathrm{M}$ ratio has no significant effect on the abnormal return of the stock.

The result of t-value $2.231>\mathrm{t}$-table that is equal to 2.045 and significance value $\mathrm{X} 3$ to $\mathrm{Y}$ that is equal to 0.033 meaning $<0.05$. Thus, it can be concluded $\mathrm{H} 0$ is rejected and $\mathrm{H} 1$ is accepted that market capitalization has a significant effect on the abnormal return of the stock.

The result of t-value $2.272>\mathrm{t}$-table that is equal to 2.045 and value of significance $\mathrm{X} 4$ to $\mathrm{Y}$ that is equal to 0.030 meaning $<0.05$. Thus, it can be concluded $\mathrm{H} 0$ rejected and $\mathrm{H} 1$ accepted that the turnover rate significantly affects the abnormal return.

The result of $\mathrm{t}$-value $2.238>\mathrm{t}$-Table that is equal to 2.045 and significance value $\mathrm{X} 5$ to $\mathrm{Y}$ that is equal to 0.033 meaning $<0.05$. Thus, it can be concluded $\mathrm{H} 1$ is accepted and $\mathrm{H} 0$ is rejected that Ivol significantly affects the abnormal return of the stock.

The calculated F-value of $4.782>$ F-Table which is 2.53 and the significance value $\mathrm{X} 1, \mathrm{X} 2$, $\mathrm{X} 3, \mathrm{X} 4, \mathrm{X} 5$ to $\mathrm{Y}$ is 0.002 which means $<0.05$. Hence, it can be concluded that $\mathrm{H} 1$ is accepted and $\mathrm{H} 0$ is rejected that Variable $\mathrm{X} 1, \mathrm{X} 2, \mathrm{X} 3, \mathrm{X} 4$, and $\mathrm{X} 5$ together significantly influence Variable $\mathrm{Y}$.

\section{CONCLUSION}

The results of this study indicate that taking into account the market capitalization, stock liquidation, and idiosyncratic risk partially is very helpful in providing the expected abnormal return as a basis for making investment decisions meaningful to potential investors in the BEI, especially for stocks in the in- dustrial sector of property and real estate. However, it will be more reinforcing if all the independent variables in this study are all collectively used as the basis for consideration in taking stock investing decisions.

\section{REFERENCES}

Bali, T. G. \& Cakici, N. 2006. World market risk, countryspecific risk and expected returns in international stock markets. Journal of Banking \& Finance 34: 1152-1165.

Basu, S. 1977. Investment performance of common stocks in relation to their price-earnings ratios: A test of the efficient market hypothesis. The Journal of Finance 32(3): 663-682.

Basu, S. 1983. The relationship between earnings' yield, market value and return for nyse common stocks: further evidence. Journal of Financial Economics 12(1): 129-156.

Berk, J., \& DeMarzo, P. 2013. Corporate Finance 3rd Edition uppl. New Jersey: Pearson Education Limited.

Fama, F. \& French, K. 1993. Common risk factors in the return on stocks and bonds. Journal of Financial Economics 33(1): 3-56.

Goyal, A. \& Santa-Clara, P. 2003. Idiosyncratic Risk Matters! The Journal of Finance 58(3 June): 975-1007.

Levy, H. 1978. Equilibrium in an imperfect market: A constraint on the number of securities in the portfolio. The American Economic Review 68(4 September): 643-658.

Liu, S \& Zhu, Z. 2009. Transaction costs and price volatility: new evidence from the Tokyo stock exchange. Journal of Financial Services Research 36(1): 65-83.

Malkiel, B.G. 2006. Idiosyncratic Risk and Security Returns. Department of Economics Princeton University, USA.

Merton, R.C. 1973. Theory of rational option pricing. The Bell Journal of Economics and Management Science 4(1 Spring): 141-183.

Setiyanto, A. 2006. Analisis likuiditas saham sebelum dan sesudah share split di Bursa Efek Jakarta periode 20032005. Yogyakarta: UII.

Tinic, S.M. \& West, R.R. 1986. Risk, resturn and equilibrium: a revisit. Journal of Political Economy 94(1 February): 126-147. 